\title{
Analysis of Climate Change Induced Parameters of South- Eastern Coastal Islands of Bangladesh: Comparison from 1977 to 2017
}

Prabal Barua*, Syed Hafizur Rahman, and Morshed Hossan Molla

\begin{tabular}{|c|c|c|c|}
\hline ece & & & \\
\hline \multicolumn{4}{|r|}{$\begin{array}{l}\text { act } \\
\text { lar- } \\
\text { esh } \\
\text { and } \\
\text { in- } \\
\text { and } \\
\text { the } \\
\text { oud } \\
\text { e is } \\
\text { on- } \\
\text { nic } \\
\text { on- } \\
\text { ker }\end{array}$} \\
\hline
\end{tabular}

Keywords: climate change, climate parameters, coastal islands, coastal inhabitants, linear regression model

\section{INTRODUCTION}

Climate, as opposed to weather, is the long-term (usually about 30 years) generalized pattern of weather conditions, including temperature, rainfall, humidity, wind, pressure, and cloudiness, in a particular area. However, in addition to the averages, the deviation from the averages, or seasonal oscillations, as well as the weather extremes, are essential components of climate. The seasonal oscillations and deviations are very pronounced in Bangladesh because of the monsoon type of climate prevailing here. In the study, 40 years long term average of the seasonal cycle of climate parameters is used for assessing the changing pattern of climate data in the three coastal islands. Forty years of data are considered long enough to calculate an average that is not affected

\section{Copyright Holder:}

(C) Barua, P., Rahman, S. H., and Molla, M. H. (2022)

\section{First Publication Right:}

Journal of Multidisciplinary Applied Natural Science

Publisher's Note:

Pandawa Institute stays neutral with regard to jurisdictional claims in published maps and institutional affiliations.

This Article is Licensed Under: by year-to-year variability [1]-[3].

Climate change poses a significant threat for Bangladesh, particularly the projected climate change effects include sea-level rise, higher temperature, enhanced monsoon precipitation, and run-off, potentially reduced dry season precipitation, and increase in cyclone intensity in the coastal region. Those threats would induce severe impediments to the socio-economic development of Bangladesh including coastal areas. A subjective ranking of key climate change effects for coastal Bangladesh identifies cyclone and sealevel rise as being of the highest priority in terms of severity, certainty, and urgency of impact. Among the 64 districts of Bangladesh, 26 districts are evidence of climate displacement in Bangladesh. Climate Displacement is a major consequence of climate change in Bangladesh because due to climate change-induced natural disasters, people are losing housing and land from their origin and are forced to be displaced in new areas to survive [4] [6].

Bangladesh ranked $7^{\text {th }}$ in the Global Climate Risk Index 2021, which said it was the seventhworst hit by climate change-induced natural disasters between 2000 and 2019, where the country lost 15,000 people, damaged the economic losses worth $\$ 3.72$ billion, and experienced 185 extreme weather events because of climate change [7]. At 


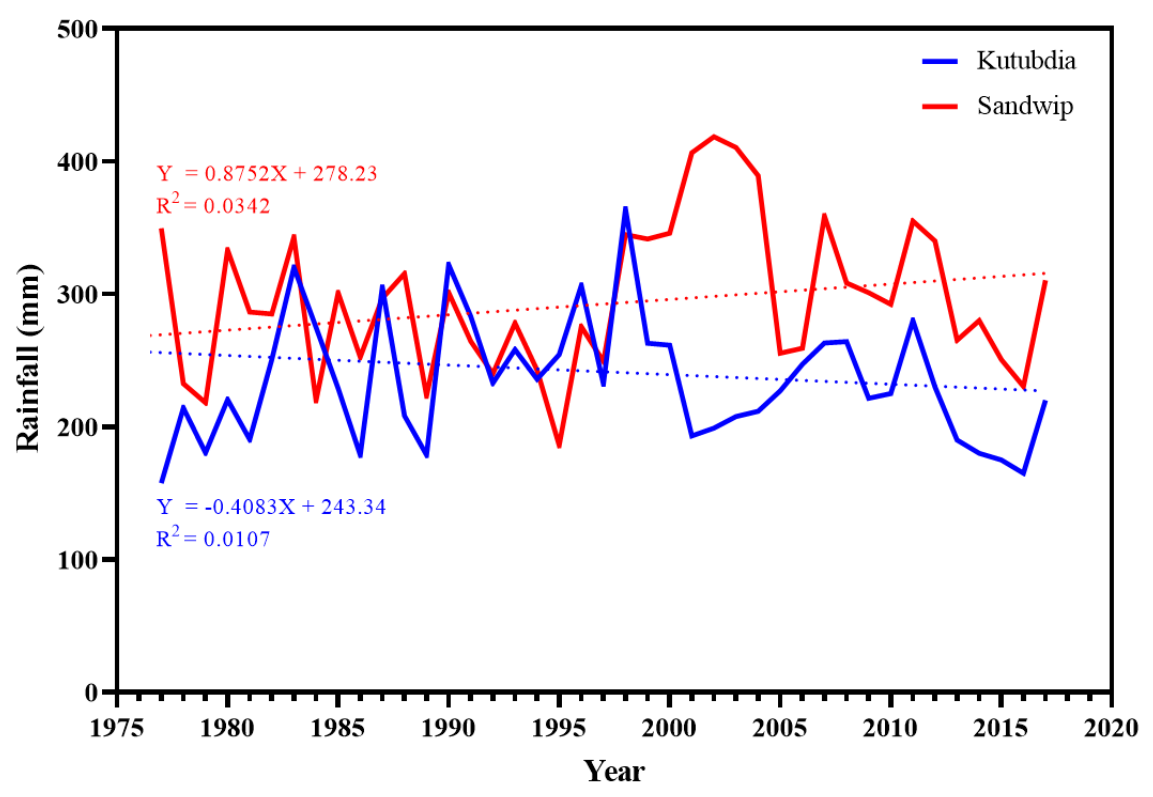

Figure 1. Rainfall pattern.

present, Bangladesh has been called the "ground zero" of climate change. However, the impact of 'climate change' is reasoning an increase in the frequency and severity of these disasters adversely affecting agriculture, water and sanitation, infrastructure, and health. Bangladesh is having a coastal area of $47,211 \mathrm{sq}$. $\mathrm{km}$, which is $32 \%$ of its entire land. The coast of Bangladesh is approximately $710 \mathrm{~km}$ long and has very low-lying flat land. $62 \%$ of the land has an elevation of fewer than three meters, and $86 \%$ have less than five meters [8]-[10].

The Coastal zone of Bangladesh is comprised of 19 administrative districts stretching into 147 Upazilas, delineated based on the tidal fluctuations, cyclone, storm surge risk, and salinity intrusion. Among the Upazilas, 48 from 12 districts face the coast or lower estuary and are known as exposed coast, and the rest 99 Upazilas that are behind the exposed coast is known as interior coast [11]-[13]. The climate of Bangladesh is conquered by seasonal reversal of winds from the southwest during summer and from the northwest during winter, consequences for wet southwest monsoon and dry north-west monsoon respectively. The South-Eastern coastal area of Bangladesh is comparatively susceptible to cyclones, tidal floods, coastal erosion, heavy rainfall that varies from year to year, both in terms of intensity and duration. Several studies were conducted on climatic trends and climate change impacts in the coastal region of Bangladesh. Analysis of global observations of surface temperature shows that there has been a warming of about $0.6{ }^{\circ} \mathrm{C}$ over the past hundred years [14]. The trend is toward a more substantial increase in minimum than in maximum daily temperatures. The reason for this difference is linked to associated increases in low cloudiness and aerosol effects as well as the enhanced greenhouse effect. Changes in precipitation and other components of the hydrological cycle are determined more by changes in the weather systems and their tracks than by changes in temperature. Because such weather systems are so variable in both space and time, patterns of change in precipitation are much more complicated than patterns of temperature change. Precipitation has increased over land in the high latitudes of the Northern Hemisphere, especially during the cold season [15][16].

From the record of temperature data over the last 100 years in Bangladesh, it is found that the rate of temperature increment found higher than the present which is $0.5^{\circ} \mathrm{C}$. Another study shows the mean annual temperature of Bangladesh has increased between 1895 and 1980 at $0.3{ }^{\circ} \mathrm{C}$ over the past two decades and from 1900 to 2017 , the rate increased by nearly $0.80{ }^{\circ} \mathrm{C}$. In general, the associated degree of the increasing trend is found in both summer and winter temperatures [17]-[19]. There was no significant trend within the annual rainfalls of Bangladesh. The study on the long-term monsoon rainfall pattern at 12 stations in Bangladesh found no overall trend in seasonal total 
rainfall but there detected some trends in monthly rainfalls [20].

Climate analysis results are also dependent on the quality of the datasets, above all on their homogeneity. This study intends to understand the trend of climate parameters such as temperature, rainfall, humidity, cloud coverage, sunshine, and wind speed over the 40 years (1977-2017) for the coastal islands of the south-eastern coast of Bangladesh through regression analysis to help farmers in increasing crop yields, minimize crop failures and equip them in adapting to erratic weather patterns and natural disasters triggered by global warming and climate change. Detection of trends in long-time series of hydrological data is of paramount scientific and practical significance.

\section{MATERIALS AND METHODS}

\subsection{Selection of the study area}

To conduct the study, researchers selected the three coastal Islands of the Southeastern coast of Bangladesh which included Sandwip and Kutubdia for analysis of climate parameters. Climate susceptibility, the trend of climate parameters, displacement rates, land erosion, recurrent disaster has been considered during the selected study areas. Regionally the study area includes the Southeastern coastal margin of Bangladesh having the complex nature of physico-chemical condition which deals with the day-to-day lifestyle of the region. Sandwip Island belongs to the Chittagong district with an area of $762.42 \mathrm{~km}^{2}$. Besides, Kutubdia Island belongs to Cox's Bazar district with an area of $215.8 \mathrm{~km}^{2}$ which is bounded by the Bay of Bengal.

\subsection{Data acquisition and analysis}

Data of climate parameters (temperature, rainfall, humidity, wind speed, cloud coverage, bright sunshine) in Kutubdia and Sandwip islands were collected from the Bangladesh Meteorological Department (BMD) from 1977 to 2017. For statistical analysis of climate parameters, the researcher used average yearly data from the time series data which were conducted on the monthly average value for the last 40 years (1977-2017).

The equation of a linear regression line is given as eq. 1 , where $y$ is the observation on the dependent variables is the observation on the independent variable ' $a$ ' is the intercept of the line on the vertical axis, and ' $b$ ' is the slope of the line. The estimate of intercept ' $a$ ' and the regression coefficient ' $b$ ' by the least square method:

$$
y=a+b x
$$

i.e. $\hat{a}=\bar{y}-\hat{b} \bar{x}$

and $\hat{b}=\frac{\sum(x-\bar{x})(y-\bar{y})}{\sum(x-\bar{x})^{2}}$

Coefficient of determination,

$$
\begin{aligned}
R^{2} & =(\text { SS due to Regression }) /(\text { Total SS }) \\
& =\frac{\sum\left(\hat{y}_{i}-\bar{y}\right)^{2}}{\sum\left(y_{i}-\bar{y}\right)^{2}}
\end{aligned}
$$

To fit regression lines of the rainy season monthly average Rainfall, Humidity, Temperature,

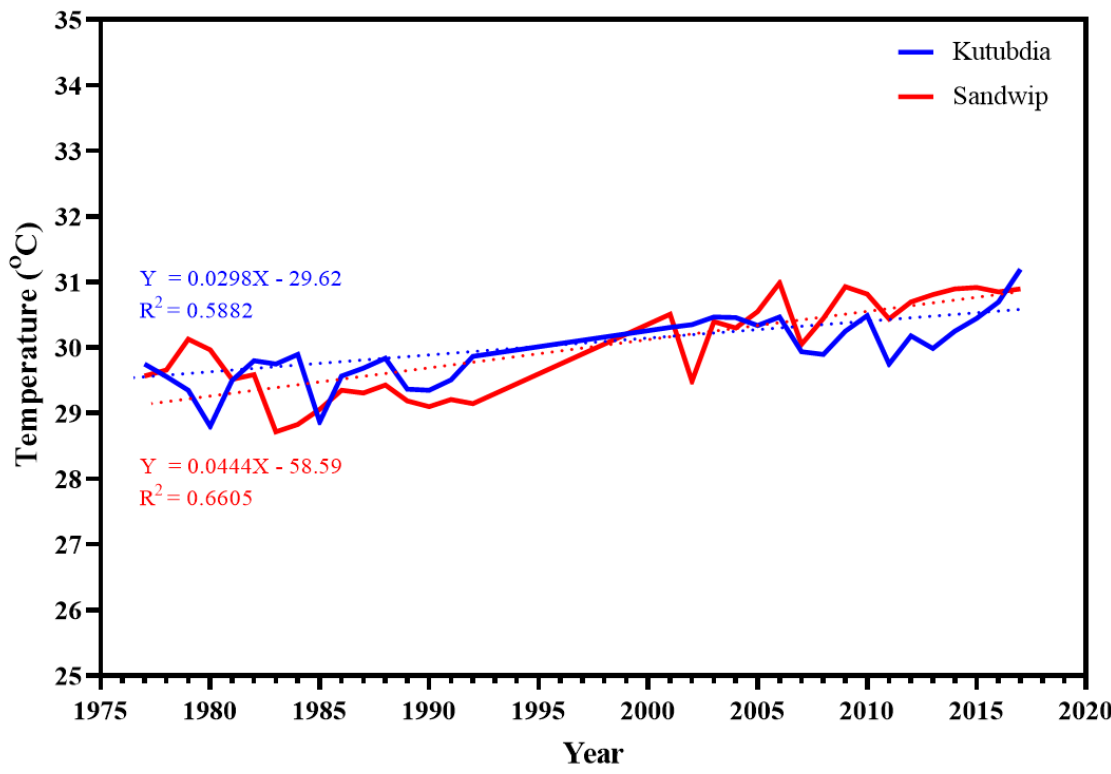

Figure 2. Changing pattern of temperature. 


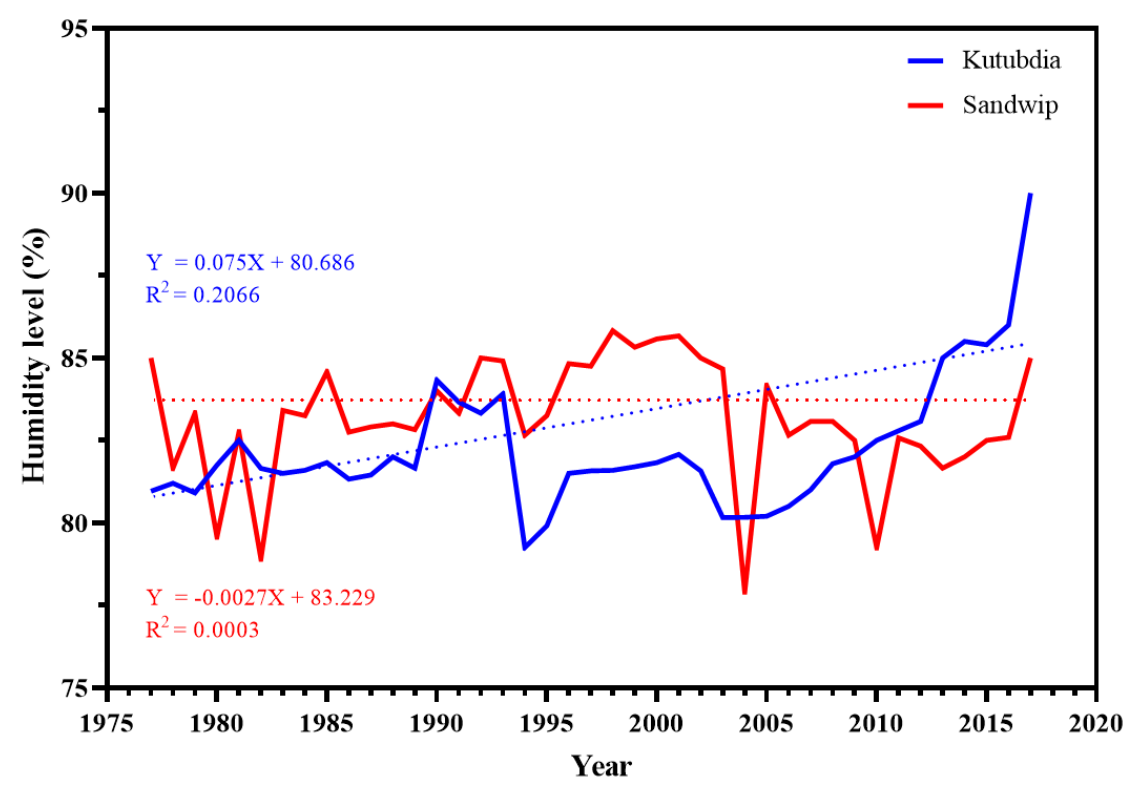

Figure 3. Changing pattern of relative humidity.

Cloud Coverage, Wind Speed, Humidity level (dependent variables) against time (independent variable) in years were plotted. Linear regression lines were then fitted to determine the trends of rainfall. The drawing of the diagrams and the fitting of the regression lines were done in Microsoft Excel. The correlation coefficient determines the strength of the linear relationship between two variables. It always takes a value between -1 and +1 , with 1 or -1 indicating a perfect correlation (all points would lie along a straight line in this case and have a residual of zero). A correlation coefficient close to or equal to zero indicates no relationship between the variables. The correlation coefficients between rainfall and time were calculated as follows. Given the pairs of values (x1, $y 1),(x 2, y 2), \ldots \ldots \ldots(x n, y n)$, the formula for computing the correlation coefficient is given by the regression equations, and the coefficient of determination $\left(\mathrm{R}^{2}\right)$ have been obtained through scattering diagrams by taking two indices at a time [21]-[23].

\section{RESULTS AND DISCUSSIONS}

\subsection{Rainfall}

Bangladesh Meteorological Department (BMD) provided the climate data for Kutubdia and Sandwip upazila over the period 1977-2017. The climate data comprised monthly, seasonal, and annual average maximum, minimum climate parameters over the period. The annual total rainfall of the study was observed. The pattern of the total rainfall for the period of 1977-2017 was irregular but increased significantly from 2015 to 2017 . For time-series data analysis of climatic components, particularly rainfall, the three climatic hotspot area's data were intended and analyzed. The following section has been depicted the real scenarios of rainfall variability in three different geographical locations. Figure 1 shows the annual mean rainfall pattern in Kutubdia upazila. Here the fixed linear regression model was $y=-0.4083 x+243.34$ and $R^{2}$ $=0.0107$. Where, $\mathrm{y}=$ year; $\mathrm{x}$, outcome variable $=$ rainfall; independent variable. Here, the intercept term 243.34 means that every year the constant maximum rainfall was 243.34 in the Kutubdia area. The regression co-efficient -0.4083 means that the rainfall decreased by $0.4083 \mathrm{~mm} /$ year.

Figure 1 indicates the annual mean rainfall pattern in Sandwip Upazila. Here the fixed linear regression line was $\mathrm{y}=0.8572 \mathrm{x}+278.23$ and $\mathrm{R}^{2}=$ 0.0342 . Where, $y=$ year; $x$, outcome variable $=$ rainfall; independent variable. Here, the intercept term 278.23 means that every year the constant maximum rainfall was 278.23 in the Sandwip area. The regression coefficient of 0.8572 means the rainfall was increased by $0.8572 \mathrm{~mm} /$ year.

\subsection{Temperature change}

Figure 2 indicates the annual mean temperature pattern in Kutubdia Upazila. Here the fixed linear regression line was $\mathrm{y}=0.0298 \mathrm{x}-29.62$ and $\mathrm{R}^{2}=$ 0.5882 . Where, $\mathrm{y}=$ year; $\mathrm{x}$, outcome variable $=$ 
temperature; independent variable. Here, the intercept term 29.62 means that every year the constant maximum temperature was 29.62 in the Kutubdia area. The regression co-efficient 0.0298 means that the temperature was increased by 0.0298 times every year. The annual mean temperature pattern in Sandwip Upazila. Here the fixed linear regression line was $\mathrm{y}=0.0444 \mathrm{x}-58.595$ and $\mathrm{R}^{2}=$ 0.6605. Where, $y=$ year; $x$, outcome variable $=$ temperature; independent variable. Here, the intercept term 58.595 means that every year the constant maximum temperature was 58.595 in the Sandwip area. The regression co-efficient 0.044 means that the temperature was increased by 0.044 ${ }^{\circ} \mathrm{C}$ per year (Figure 2). Thus, the changing pattern of temperature in the two study areas was positively changed. Last 42 years (from 1977 to 2017) climatic years, the temperature was changing nearly (+) $1.25{ }^{\circ} \mathrm{C}$ in Kutubdia Upazila, $(+)$ and $1.85{ }^{\circ} \mathrm{C}$ in Sandwip upazila respectively. Among the 2 study locations, Sandwip upazila was increased temperature among these regions.

\subsection{Humidity level}

Figure 3 illustrates the annual mean humidity pattern in Kutubdia Upazila. Here the fixed linear regression line was $y=0.075 x+80.686$ and $R^{2}=$ 0.2066. Where, $y=$ year; $x$, outcome variable $=$ humidity; independent variable. Here, the intercept term 80.686 means that every year the constant maximum humidity was 80.686 in the Kutubdia area. The regression co-efficient 0.075 means that the humidity level increased by $0.075 \%$ per year.
The annual mean humidity pattern in Sandwip Upazila. Here the fixed linear regression line was $y$ $=-0.0027 x+83.229$ and $R^{2}=0.0003$. Where, $y=$ year; $\mathrm{x}$, outcome variable $=$ humidity; independent variable. Here, the intercept term 83.229 means that every year the constant maximum humidity was 83.229 in the Sandwip area. The regression coefficient -0.0027 means that the humidity level decreased $0.0027 \%$ per year.

\subsection{Wind speed}

Figure 4 indicates Kutubdia has a special and potential natural resource which is wind for electricity production. Figure 7 indicates the annual mean wind speed pattern in Kutubdia Upazila. Here the fixed linear regression line was $y=0.0643 x+$ 1.422 and $\mathrm{R}^{2}=0.627$. Where, $\mathrm{y}=$ year; $\mathrm{x}$, outcome variable $=$ wind speed; independent variable. Here, the intercept term 1.422 means that every year the constant maximum wind speed was $1.422 \mathrm{~m} / \mathrm{s}$ in the Kutubdia area. The regression co-efficient 0.064 means that the wind speed was increased by 0.064 $\mathrm{m} /$ year. Figure 4 indicates the annual mean wind speed pattern in Sandwip Upazila. Here the fixed linear regression line was $y=0.068 x+0.705$ and $\mathrm{R}^{2}=0.3731$. Where, $\mathrm{y}=$ Year; $\mathrm{x}$, outcome variable $=$ wind speed; independent variable. Here, the intercept term 0.705 means that every year the constant maximum wind speed was $0.705 \mathrm{~m} / \mathrm{s}$ in Sandwip Upazila. The regression co-efficient 0.068 means the wind speed was increased by $0.068 \mathrm{~m} /$ year.

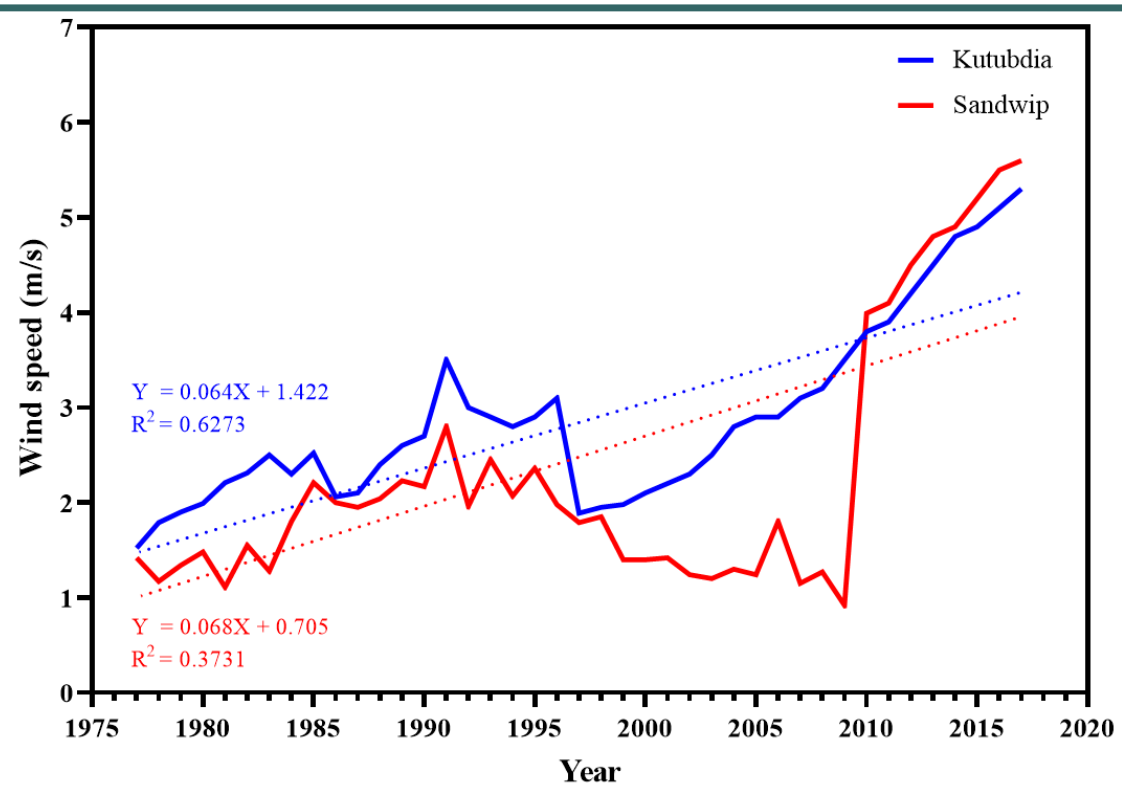

Figure 4. Changing pattern of wind speed. 


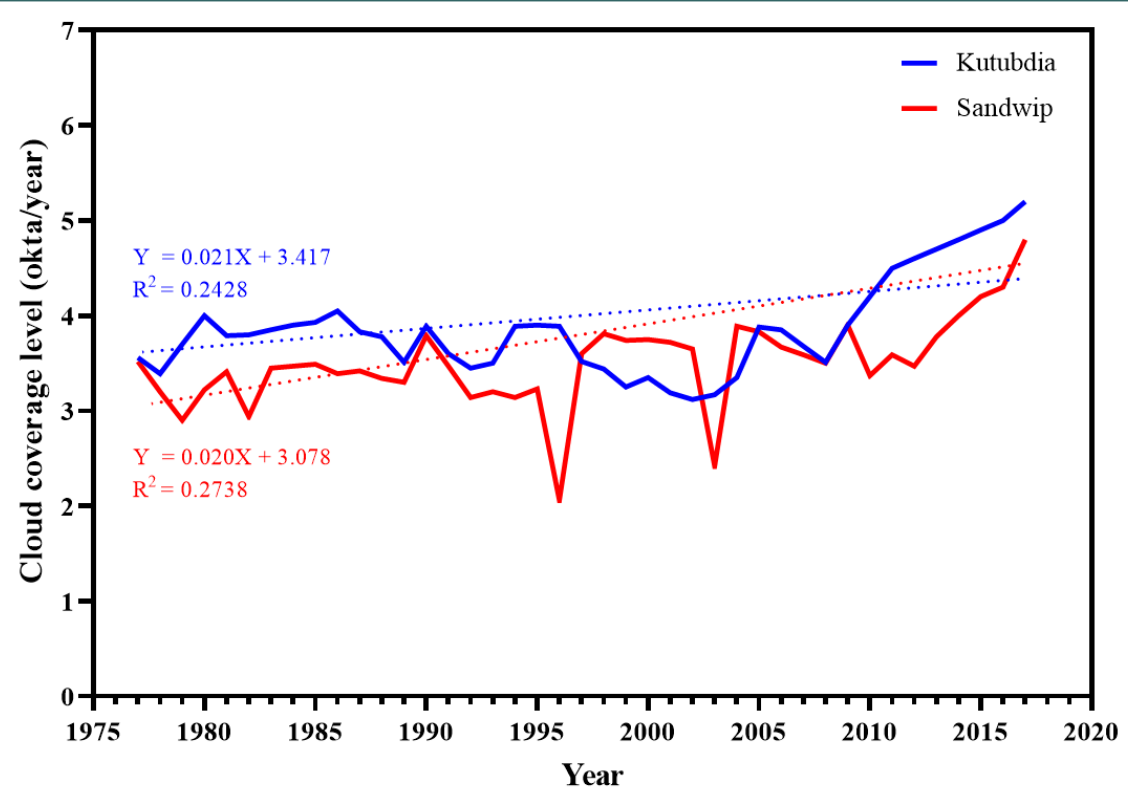

Figure 5. Changing pattern of cloud coverage.

\subsection{Cloud coverage}

Figure 5 indicates the annual mean cloud coverage pattern in Kutubdia Upazila. Here the fixed linear regression line was $\mathrm{y}=0.021 \mathrm{x}+3.417$ and $\mathrm{R}^{2}=0.2428$. Where, $\mathrm{y}=$ year; $\mathrm{x}$, outcome variable $=$ cloud coverage; independent variable . Here, the intercept term 3.417 means that every year the constant maximum cloud coverage was 3.417 okta/year in Kutubdia Upazila. The regression co-efficient 0.021 means the cloud coverage was increased by $0.021 \mathrm{okta} / \mathrm{year}$. Figure 5 explores the annual mean cloud coverage pattern in Sandwip upazila. Here the fixed linear regression line was $\mathrm{y}=0.0203 \mathrm{x}-36.979$ and $\mathrm{R}^{2}=0.2738$. Where, $y=$ year; $\mathrm{x}$, outcome variable $=$ cloud coverage; independent variable. Here, the intercept term 3.078 means that every year the constant maximum cloud coverage was 3.078 in Sandwip upazila. The regression coefficient of 0.020 means the cloud coverage increased by $0.020 \mathrm{okta} / \mathrm{year}$.

\subsection{Sunshine}

Figure 6 indicates the mean bright sunshine pattern in Kutubdia Upazila. Here the fixed linear regression line was $\mathrm{y}=-0.062 \mathrm{x}+8.540$ and $\mathrm{R}^{2}=$ 0.6094 . Where, $y=$ year; $x$, outcome variable $=$ bright sunshine; independent variable. Here, the intercept term 8.540 means that every year the constant maximum bright sunshine was 8.540 in Kutubdia Upazila. The regression coefficient -0.062 means the bright sunshine decrease by 0.062 every year. Figure 6 shows the mean bright sunshine pattern in Sandwip Upazila. Here the fixed linear regression model was $\mathrm{y}=-0.067 \mathrm{x}+8.270$ and $\mathrm{R}^{2}=$ 0.6967. Where, $\mathrm{y}=$ year; $\mathrm{x}$, outcome variable $=$ bright sunshine; independent variable. Here, the intercept term 8.270 means that every year the constant maximum bright sunshine was 8.270 in Sandwip Upazila. The regression coefficient -0.067 means the bright sunshine decrease by 0.067 every year.

The study found the increasing trend of temperature for Kutubdia and Sandwip $(+) 0.029^{\circ} \mathrm{C}$ and (+) $0.044{ }^{\circ} \mathrm{C}$ from 1977 to 2017 respectively. Besides, Ghosh et al. [22] mentioned that the average minimum temperature in the Kutubdia area was recorded from November to February and varied generally from $6.2{ }^{\circ} \mathrm{C}$ to $13.4{ }^{\circ} \mathrm{C}$; while the maximum temperature of $39.5^{\circ} \mathrm{C}$ is observed in May. Thus, the correlation coefficient between year and temperature was positive for all the study areas. Rainfall variability in space and time is one of the most relevant characteristics of the climate of Bangladesh. This will cause a cruel combination of more extreme floods and longer periods of droughts. Bangladesh has been termed as one of the most vulnerable countries in the world due to climatic change [24]. The trend of rainfall (19772017) is calculated to envisage the temporal pattern of rainfall in Bangladesh. The authors found the increasing pattern of rainfall in Kutubdia was 1.957 $\mathrm{mm} /$ year and $0.875 \mathrm{~mm} /$ year at Sandwip. The correlation coefficient between year and rainfall was positive for the study areas. During 1961-1991 
Table 1. List of Major Cyclonic Storm's heat in South-Eastern coast from 1977 to 2017.

\begin{tabular}{|c|c|c|c|c|c|}
\hline $\begin{array}{c}\text { Date of } \\
\text { Occurrence }\end{array}$ & Nature of Phenomenon & $\begin{array}{l}\text { Maximum } \\
\text { Wind Speed } \\
(\mathrm{km} / \mathrm{hr})\end{array}$ & $\begin{array}{c}\text { Tidal Surge } \\
\text { Height } \\
\text { (ft) }\end{array}$ & Death & $\begin{array}{c}\text { People } \\
\text { Displaced }\end{array}$ \\
\hline 15.10 .83 & Cyclonic Storm & 93 & 3 & 50 & 5,000 \\
\hline 09.11 .83 & Severe Cyclonic Storm & 136 & 5 & 300 & 15,000 \\
\hline 24.05 .85 & Severe Cyclonic Storm & 154 & 15 & 12000 & 45,000 \\
\hline 18.12 .90 & $\begin{array}{l}\text { Cyclonic Storm (crossed as a } \\
\text { depression) }\end{array}$ & 115 & $5-7$ & 400 & 20,000 \\
\hline 29.04 .91 & $\begin{array}{l}\text { Severe Cyclonic Storm with a } \\
\text { core of hurricane wind }\end{array}$ & 225 & $12-22$ & 150,000 & 450,000 \\
\hline 02.05 .94 & $\begin{array}{l}\text { Severe Cyclonic Storm with a } \\
\text { core of hurricane wind }\end{array}$ & 278 & $5-6$ & 400 & 15,000 \\
\hline 25.11 .95 & Severe Cyclonic Storm & 140 & 10 & 650 & 30,000 \\
\hline 19.05.97 & $\begin{array}{l}\text { Severe Cyclonic Storm with a } \\
\text { core of hurricane wind }\end{array}$ & 232 & 15 & 150 & 15,000 \\
\hline 27.09 .97 & $\begin{array}{l}\text { Severe Cyclonic Storm with a } \\
\text { core of hurricane wind }\end{array}$ & 150 & $10-15$ & 30 & 12,000 \\
\hline 20.05 .98 & $\begin{array}{l}\text { Severe Cyclonic Storm with a } \\
\text { core of hurricane winds }\end{array}$ & 173 & 3 & 45 & 20,000 \\
\hline 16.05 .13 & Cyclonic Storm (MAHASEN) & 100 & 5 & 25 & 70,000 \\
\hline 30.07 .15 & Cyclonic Storm (KOMEN) & 100 & $5-7$ & 132 & 120,000 \\
\hline 21.05 .16 & Cyclonic Storm (Ruano) & 120 & $7-8$ & 25 & 100,000 \\
\hline 29.05 .17 & Cyclonic Storm ( Mora) & 130 & $5-7$ & 20 & 70,000 \\
\hline
\end{tabular}

Bangladesh faced 19 droughts. Major drought occurred in 1973, 1976, 1978, 1979, 1980, 1981, 1982, 1984, 1986 and 2000. It was noticeable that in 1979 rainfall was abruptly decreased and severe drought caused widespread damage to crops. The consecutive droughts of 1979 directly affected about $42 \%$ of cultivated land, $44 \%$ of the population, and reduced rice production by an estimated 2 million tons and it was one of the severest in recent times [25]. The increasing trends in annual maximum rainfalls in Kutubdia and Sandwip upazila are eventually the path of traverse of the south-western monsoon wind. This indicates that the intensity of heavy rainfall may have increased along the main route of the monsoon wind. Relative humidity $(\mathrm{RH})$ is another important climatic factor and is also responsible for the formation of any kind of unsteady condition. Study on this parameter is also important because temperature and $\mathrm{RH}$ relate good influence on the formation of the cyclone [26]-[28].
The study found significant changes in wind speed over the study areas. During the initiation time of the study area in 1977, the wind speed of Kutubdia and Sandwip were $1.9 \mathrm{~m} / \mathrm{s}$ and $1.45 \mathrm{~m} / \mathrm{s}$. During 2017, the average wind speed of the 2 study areas was now $5.5 \mathrm{~m} / \mathrm{s}$ and $5.7 \mathrm{~m} / \mathrm{s}$ in Kutubdia and Sandwip respectively. Hoque et al., [29] assess the wind speed of Sandwip for the design of a wind farm in the coastal island Sandwip. They calculated the data for one year 2015 round and found that the average wind speed is $3.56 \mathrm{~m} / \mathrm{s}$ at Sandwip. The recent development of wind rotor aerodynamics makes it feasible to extract energy from wind speed as low as $2.0 \mathrm{~m} / \mathrm{s}$. Considering the per capita demand, the electricity demand of Kutubdia was $138250 \mathrm{MWh}$ in 2011 and $378 \mathrm{MWh}$ per day. On the other hand, the Southern and Eastern part of Kutubdia emerges to be gifted for wind electricity generation using large turbines where wind power density at the height of $50 \mathrm{~m}$ or higher is found to be above $200 \mathrm{~W} / \mathrm{m}^{2}$ annually over the year 
Table 2. Numbers of climate displaced peoples of the study areas from 1977 to 2017.

\begin{tabular}{lclll}
\hline \multicolumn{1}{c}{ District } & Upazila & \multicolumn{1}{c}{ Reason for Displacement } & $\begin{array}{c}\text { Displaced } \\
\text { Peoples }\end{array}$ & \multicolumn{1}{c}{ Destination } \\
\hline Chittagong & Sandwip & $\begin{array}{l}\text { Cyclone, Erosion, Tidal Inunda- } \\
\text { tion, and Water Logging. }\end{array}$ & 150,000 & $\begin{array}{l}\text { Chittagong and Cox's } \\
\text { Bazar }\end{array}$ \\
Cox's Bazar & Kutubdia & $\begin{array}{l}\text { Cyclone, Erosion, Tidal Inunda- } \\
\text { tion, Sudden Flood, and Water } \\
\text { Logging. }\end{array}$ & 200,000 & Cox's Bazar \\
Total & & 250,000 & \\
\hline
\end{tabular}

Source: Barua et al. [6]

September 1996 to August 1997. It is found that at $30 \mathrm{~m}$ height, the coast side of Kutubdia should be sustainable for small turbines [27].

During the study, the authors found that cyclonic storm surge responsible for enormous life and property losses for the inhabitants of the Kutubdia and Sandwip islands. From the literature, it is found that 31 cyclones occurrence in the Bay of Bengal and responsible for disruption of significant damages to the assets and human life in the study areas (Table 1). From the statistics of cyclone history of 1960 to 2017, approximately, 574,000 inhabitants of the south-eastern coast of Bangladesh experienced displacement from their home and living land. Inhabitants of Kutubdia and Sandwip islands stated that 350,000 inhabitants of Kutubdia and Sandwip islands have been forced to displaced and migrated from their living places from 1980 to 2018 because of natural disasters such as cyclones, tidal flood, coastal erosion, and waterlogging problem (Table 2).

One of the researchers found that Bangladesh higher rate of cloud cover from June to August and in July it is maximum. He mentioned that the cloud cover of different locations in Bangladesh is not the same. Geological position, humidity variation, plant density, wind speed variation, temperature changes, etc. are important parameters to form clouds and causes for cloud cover variation [28]. During the investigation, the authors found average cloud coverage in Kutubdia, and Sandwip in 2017 was 5.2 okta/sec and $4.7 \mathrm{okta} / \mathrm{sec}$ while the cloud coverage was $3.56 \mathrm{okta} / \mathrm{sec}$ and $3.52 \mathrm{okta} / \mathrm{sec}$ in $1977 \mathrm{on}$ Kutubdia and Sandwip respectively. Besides, the annual average cloud coverage from 1953 to 2011 in Kutubdia and Sandwip was $3.45 \mathrm{okta} / \mathrm{sec}$ and $3.27 \mathrm{okta} / \mathrm{sec}$ respectively [29][30]. The correlation coefficient (r) between cloud cover with temperature, humidity, and rainfall is large and positive. It means the cloud cover rate is increased with the increasing value of temperature and humidity. It also means rainfall rate increases with the increase of cloud cover in the sky. On the other hand, the author found the decreasing rate of bright

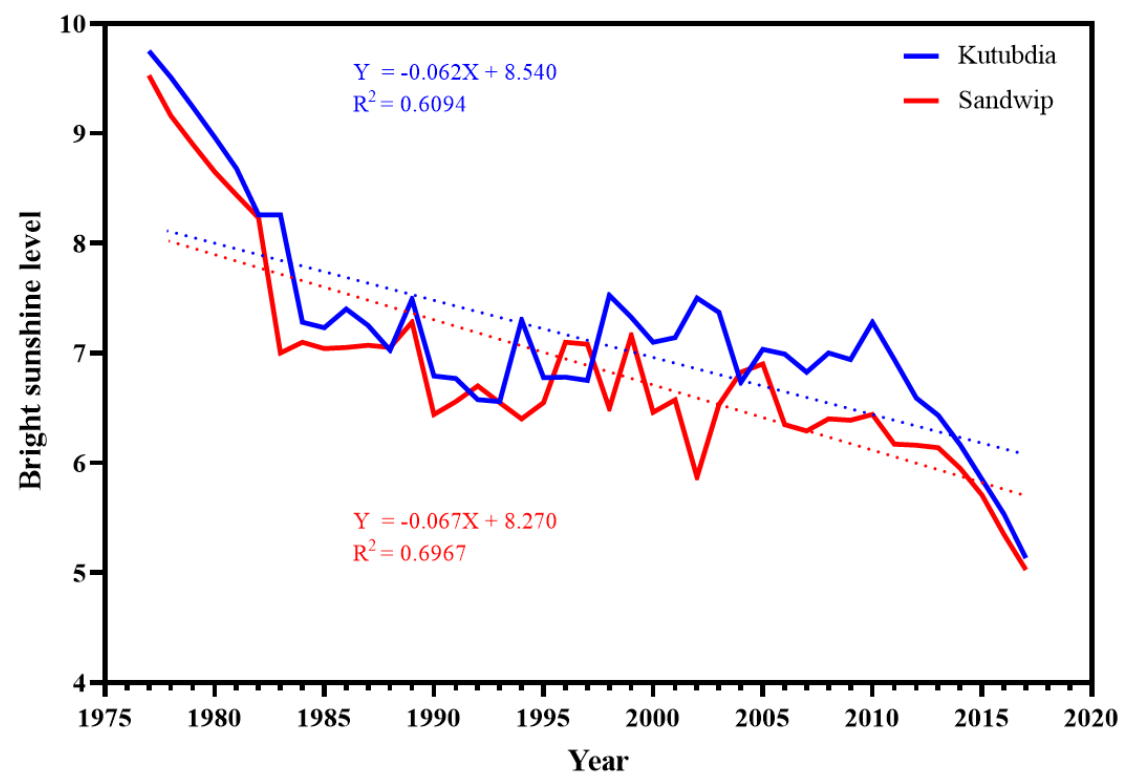

Figure 6. Changing pattern of bright sunshine level. 
sunshine levels in Kutubdia and Sandwip was $0.0216 \mathrm{~m} / \mathrm{sec}$ times and $0.039 \mathrm{~m} / \mathrm{sec}$ per year from the 1977 to 2017 timeline.

\section{CONCLUSIONS}

The finding of the study describes the changing pattern of annual climate parameters like temperature, rainfall, humidity, bright sunshine, cloud coverage, and wind speed for Kutubdia and Sandwip Island from 1977 to 2017. Long-term year -to-year anomalies over 40 years show that the increasing pattern of Kutubdia and Sandwip upazila are not the same in a consecutive year. Of all climate parameters, rainfall is the single most crucial variable which has been widely considered as one of the starting points towards the apprehension of climate change courses. Most of the island dwellers frequently complained that they might not survive very long if government agencies would not do anything for them. For protection from coastal erosion, some households have applied hard structures in parallel with the coast to protect their house/ land which is - heightening of the dike, bamboo revetment, and Concrete-pole breakwater. The function of such construction is to lessen the impact of waves and storms. The individual options cannot substitute for others but rather support other options. So, from the finding of the study, it was found the somewhat increase in temperature, rainfall, humidity, cloud coverage, wind speed but decreased in the bright sunshine level over the coastal islands of the south-eastern coast of Bangladesh has been observed during the last forty years. However, the data and the analysis presented in the paper are inadequate to remark about the global climate change impact on climate trends in the south-eastern islands of Bangladesh. Increased temperature, rainfall, and monsoon precipitation are probably responsible for the frequent tropical disease outbreak and raised sternness and incidence of hydrological different disasters. On the other hand, amplified rainfall could assist to remain the groundwater in balance and agriculture production in the coastal areas. This is anticipated that the climate trend maps and the research finding will support to outline of the planning of climate change policy perspective in Bangladesh and to understand the regional climate changes to realize the broad features of the Asian coupled-land-atmospheric system.

\section{AUTHOR INFORMATION}

\section{Corresponding Author}

Prabal Barua - Department of Environmental Sciences, Jahangirnagar University, Dhaka 1342 (Bangladesh);

orcid.org/0000-0003-1372-0042

Email:prabalims@gmail.com

\section{Authors}

Syed Hafizur Rahman - Department of Environmental Sciences, Jahangirnagar University, Dhaka - 1342 (Bangladesh); orcid.org/0000-0003-0112-9124

Morshed Hossan Molla - Department of Geography and Environmental Studies, University of Chittagong, Chittagong - 4331 (Bangladesh); orcid.org/0000-0001-6012-3238

\section{ACKNOWLEDGEMENT}

The authors express the highly acknowledged to the Bangladesh Meteorological Department officials for providing the climate parameters statistics over the mentioned period 1977 to 2017 which help to conduct the research study successfully.

\section{REFERENCES}

[1] S. Hastenrath, A. Nicklis, and L. Greischar. (1993). "Atmospheric-hydrospheric mechanisms of climate anomalies in the western equatorial Indian Ocean". Journal of Geophysical Research. 98 (3): 20219-20235. 10.1029/93jc02330.

[2] N. H. Saji, B. N. Goswami, P. N. Vinayachandran, and T. Yamagata. (1999). "A dipole mode in the tropical Indian ocean". Nature. $401 \quad$ (6751): $\quad 360-363$. 10.1038/43854.

[3] J. Hansen, M. Sato, P. Kharecha, and K. Von Schuckmann. (2011). "Earth's energy imbalance and implications". Atmospheric Chemistry and Physics. 11 (24): 13421- 
13449. 10.5194/acp-11-13421-2011.

[4] P. Barua, S. H. Rahman, and M. H. Molla. (2017). "Sustainable adaptation for resolving climate displacement issues of south eastern islands in Bangladesh". International Journal of Climate Change Strategies and Management. 9 (6): 790-810. 10.1108/ IJCCSM-02-2017-0026.

[5] R. W. Bell, M Mainuddin, E. G. BarrettLennard, S K. Sarangi, M. Maniruzzaman, K. Brahmachari, K. K. Sarker, D. Burman, D. S. Gaydon, J. M. Kirby, M. Glover, M. S. I. Khan, M. E. Kabir, M. A. Rahman, M. B. Hossain. (2019). "Cropping Systems Intensification in the Coastal Zone of the Ganges Delta: Opportunities and Risks". Journal of Indian Society of Coastal Agricultural Research. 37 (2): 153-161.

[6] P. Barua, S. H. Rahman, and M. H. Molla. (2020). "Impact of river erosion on livelihood and coping strategies of displaced people in South-Eastern Bangladesh". International Journal of Migration and Residential Mobility. $\quad 2 \quad$ (1): $34 . \quad$ 10.1504/ ijmrm.2019.10024811.

[7] D. Eckstein, K. Vera, and L. Schäfer. (2021). "Global Climate Risk Index 2021: Who Suffers Most from Extreme Weather Events (2021): 2000-2019". Berlin, Heidelberg.

[8] B. Mallick. (2014). "Cyclone shelters and their locational suitability: an empirical analysis from coastal Bangladesh". Disasters. 38 (3): 654-671. 10.1111/disa.12062.

[9] M. R. Islam and M. Shamsuddoha. (2017). "Socioeconomic consequences of climate induced human displacement and migration in Bangladesh". International Sociology. 32 (3): 277-298. 10.1177/0268580917693173.

[10] M. B. Sikder, A. H. M. A. Baqee, S. Begum, and M. N. Kabir. (2021). In: "M. N. Islam and A. van Amstel (Eds) Bangladesh II: Climate Change Impacts, Mitigation and Adaptation in Developing Countries". Springer, Cham. 10.1007/978-3-030-71950$0 \quad 10$.

[11] K. E. Trenberth, J. T. Fasullo, and T. G. Shepherd. (2015). "Attribution of climate extreme events". Nature Climate Change. 5 (8): 725-730. 10.1038/nclimate2657.
[12] M. Latif, E. Roeckner, M. Botzet, M. Esch, H. Haak, S. Hagemann, J. Jungclaus, S. Legutke, S. Marsland, U. Mikolajewicz, J. Mitchell. (2004). "Reconstructing, Monitoring, and Predicting MultidecadalScale Changes in the North Atlantic Thermohaline Circulation with Sea Surface Temperature." Journal of Climate. 17 (7): 1605-1614. 10.1175/1520-0442(2004) 017<1605:RMAPMC $>2.0 . C O ; 2$.

[13] C. M. Brierley and A. V. Fedorov. (2010). "Relative importance of meridional and zonal sea surface temperature gradients for the onset of the ice ages and Pliocene-Pleistocene climate evolution". Paleoceanography. 25 (2). 10.1029/2009PA001809.

[14] M. Shaltout and A. Omstedt. (2014). "Recent sea surface temperature trends and future scenarios for the Mediterranean Sea". Oceanologia. 56 (3): 411-443. 10.5697/oc.56 -3.411 .

[15] A. E. Dessler. (2013). "Observations of climate feedbacks over 2000-10 and comparisons to climate models". Journal of Climate. 26 (1): 333-342. 10.1175/JCLI-D11-00640.1.

[16] A. Donohoe, K. C. Armour, A. G. Pendergrass, and D. S. Battisti. (2014). "Shortwave and longwave radiative contributions to global warming under increasing $\mathrm{CO}_{2}$ ". Proceedings of the National Academy of Sciences of the United States of America. 111 (47): 16700-16705. 10.1073/ pnas. 1412190111.

[17] M. Rouf, M. Uddin, S. Debsarma, and M. M. Rahman. (2011). "Climate of Bangladesh: An Analysis of Northwestern and Southwestern Part Using High Resolution AtmosphereOcean General Circulation Model (AOGCM)". The Agriculturists. 9 (1-2): 143 -154. 10.3329/agric.v9i1-2.9489.

[18] S. Shahid, S. Bin Harun, and A. Katimon. (2012). "Changes in diurnal temperature range in Bangladesh during the time period 1961-2008". Atmospheric Research. 118 : 260-270. 10.1016/j.atmosres.2012.07.008.

[19] S. Shahid, X. J. Wang, and S. Harun. (2014). "Unidirectional trends in rainfall and temperature of Bangladesh". IAHS-AISH 
Proceedings and Reports. 363 : 177-182.

[20] M. Ahasan, M. A. Chowdhary, and D. Quadir. (2010). "Variability and Trends of Summer Monsoon Rainfall over Bangladesh". Journal of Hydrology and Meteorology. 7 (1): 1-17. $\quad$ 10.3126/ jhm.v7i1.5612.

[21] R. A. Bradley, B. W. Lindgren, and G. W. McElrath. (1960). "Introduction to Probability and Statistics". The American Mathematical Monthly. $67 \quad$ (7): 708. 10.2307/2310140.

[22] M. Ghosh, L. Kumar, and C. Roy. (2017). "Climate Variability and Mangrove Cover Dynamics at Species Level in the Sundarbans, Bangladesh". Sustainability. 9 (5): 805. 10.3390/su9050805.

[23] M. Clavero, D. Villero, and L. Brotons. (2011). "Climate Change or Land Use Dynamics: Do We Know What Climate Change Indicators Indicate?". PLoS ONE. 6 (4): e18581. 10.1371/journal.pone.0018581.

[24] M. A. Rahman. (2018). "Governance matters: climate change, corruption, and livelihoods in Bangladesh". Climatic Change. 147 (1-2): 313-326. 10.1007/s10584-018-2139-9.

[25] M. R. Chowdhury. (2003). "The El NiñoSouthern Oscillation (ENSO) and seasonal flooding - Bangladesh". Theoretical and Applied Climatology. 76 (1-2): 105-124. 10.1007/s00704-003-0001-z.

[26] S. Bahrebar and R. Ambat. (2021). "Investigation of critical factors effect to predict leakage current and time to failure due to ECM on PCB under humidity". Microelectronics Reliability. 127 : 114418. 10.1016/j.microrel.2021.114418.

[27] Z. Li, Y. Xue, Y. Fang, and K. Li. (2021). "Modulation of environmental conditions on the significant difference in the super cyclone formation rate during the pre- and postmonsoon seasons over the Bay of Bengal". Climate Dynamics. 57 (9-10): 2811-2822. 10.1007/s00382-021-05840-7.

[28] C. Tian, W. Jiao, D. Beysens, K. Farai Kaseke, M. G. Medici, F. Li, L. Wang. (2021). "Investigating the role of evaporation in dew formation under different climates using 170-excess". Journal of Hydrology.
592. 10.1016/j.jhydrol.2020.125847.

[29] M. N. Hoque, S. K. Nandi, and H. R. Ghosh. (2016). "Wind resource assessment for southern part of Bangladesh". Asian Journal on Energy and Environment. 11 (1): 1-9.

[30] F. Hossain, I. Jeyachandran, and R. Pielke. (2010). "Dam safety effects due to human alteration of extreme precipitation". Water Resources Research. $46 \quad$ (3): 10.1029/2009WR007704. 